\title{
Paleogeography and Sequence Stratigraphy in Dariyan Carbonate Reservoir, NE Shiraz
}

\author{
Amir Karimian Torghabeh¹, Nuno Pimentel ${ }^{2}$ \\ ${ }^{1}$ Department of Earth Sciences, Faculty of Sciences, Shiraz University, Shiraz, Iran \\ ${ }^{2}$ IDL, Faculty of Sciences, Lisbon University, Lisbon, Portugal \\ Email: amirkarimian@shirazu.ac.ir
}

How to cite this paper: Karimian Torghabeh, A. and Pimentel, N. (2016) Paleogeography and Sequence Stratigraphy in Dariyan Carbonate Reservoir, NE Shiraz. Open Journal of Geology, 6, 1423-1433. http://dx.doi.org/10.4236/ojg.2016.611101

Received: September 21, 2016 Accepted: November 18, 2016 Published: November 21, 2016

Copyright $\odot 2016$ by authors and Scientific Research Publishing Inc. This work is licensed under the Creative Commons Attribution International License (CC BY 4.0).

http://creativecommons.org/licenses/by/4.0/

\begin{abstract}
Zagros Basin is a very important hydrocarbon region in the Iran and World. One of the major reservoirs in this basin is the Lower Cretaceous Dariyan Formation. Based on petrographic studies, 9 microfacies were determined and interpreted as related to lagoon, barrier island and open marine environments. Facies associations show deposition in a carbonate ramp. Sequence stratigraphy studies show two sequences, each one with a transgressive system tract, marked by open marine microfacies, and then a retrogradational highstand, marked by barrier and lagoonal facies. Paleogeography and sequence stratigraphy studies of this formation and correlation of it with other sections may provide useful information about reservoir characterizations.
\end{abstract}

\section{Keywords}

Dariyan Formation, Reservoir, Microfacies, Sequence Stratigraphy, Paleogeography

\section{Introduction}

The Dariyan Formation is part of the Lower Cretaceous deposits of southwest of Iran. This formation is one of the important hydrocarbon reservoirs in the Zagros basin, southwest of Iran. This Formation is equivalent with Shaiba Formation in countries in south of Persian Gulf [1]. In the Fars region this Lower Cretaceous formation consists of shallow limestone with wackstone-packstone textures and is deposited in carbonate ramp environments [1] [2] [3]. Lower and upper boundaries of Dariyan formation are transitional for the Fahliyan and Kazdomi Formations, respectively.

\section{Material and Methods}

The studied section is located around 93 kilometers NE of Shiraz, close to Arsanjan, at Kamal Abad village (Figure 1). First, in this study 120 outcrop samples were selected for thin-section petrography, including microfacies characterization and interpretation, 


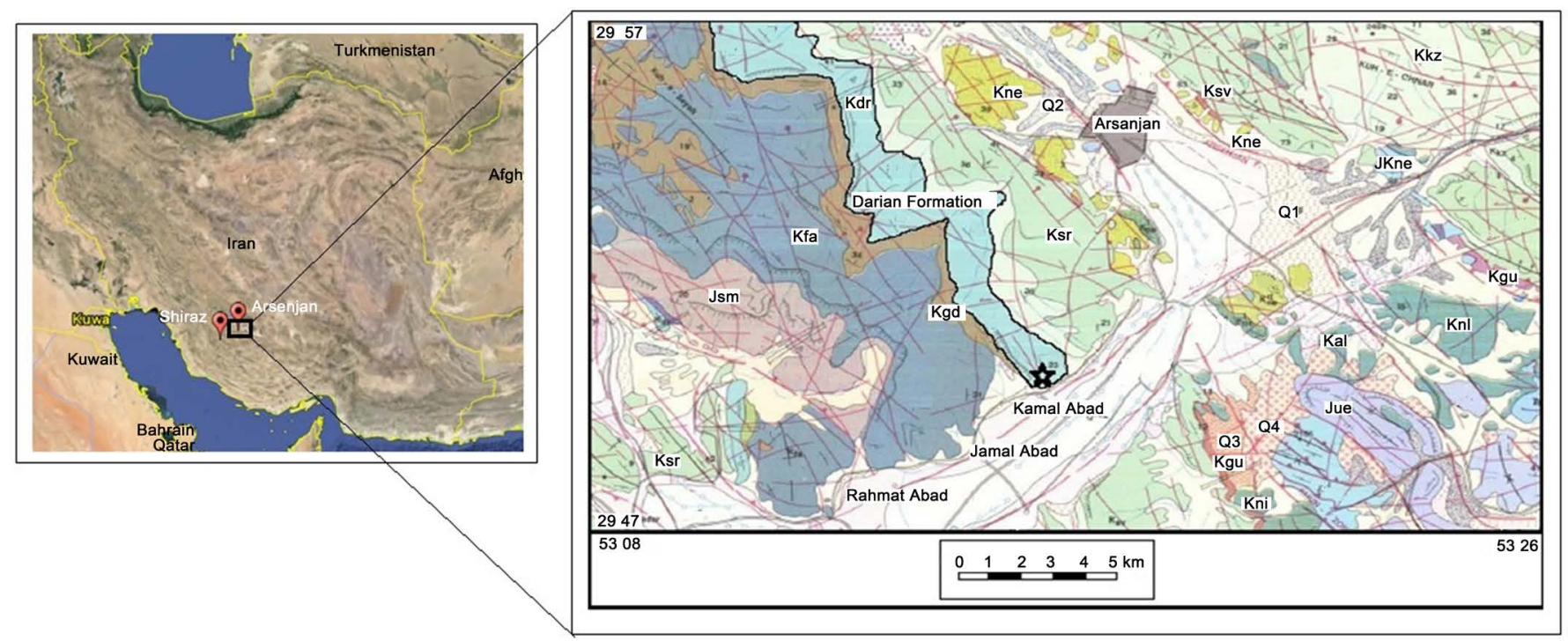

Figure 1. Location map of the studied section. Dariyan Fm formation outcropping area is represented in light blue and the studied location (Kamal Abad) is indicated by a star. Jsm = Surmeh Fm; Kfa = Fahlian Fm; Kdr = Dariyan Fm; Kgd = Gadvan Fm; Kkz = Kazdumi Fm; Ksv = Sarvak Fm; Kgu = Gurpi Fm; Kne, Knl = Neyriz Radiolarite Subzones; Q1-4 = Quaternary Deposites.

as well as sequence stratigraphy approach and paleogeographic reconstruction. Dunham (1962) [4] was used for classification of carbonate rocks and Flugel (2004) [5] was used to describe microfacies.

\section{Microfacies and Paleoenvironments}

Based on detailed petrographic studies of 120 samples, 9 specific microfacies were determined. Its paleoenvironmental interpretation points to lagoonal, barrier island and open marine environments. Theses microfacies include as following (Figure 2).

\subsection{A: Open Marine Microfacies}

\subsubsection{A1: Crinoid Planktonic Bioclastic Mudstones}

This facies consists mainly of skeletal grains $(5 \%-10 \%)$, including crinoids and pelagic foraminifera in a micritic matrix. Evidences such as pelagic bioclasts, dark-couloured micritic matrix and absence of calcareous algae, indicate a deposition in open marine environments (e.g. [5]).

\subsubsection{A2: Skeletal Wackstones}

The most important components of this facies are lenticular Orbitolina (15\% - 20\% with $0.5-1 \mathrm{~cm}$ diameter), bivalve debris and peloids. With notice to skeletal grains, the abundance of discoidal Orbitolinids (as in other lower cretaceous units) [6], points to very shallow marine conditions.

\subsection{B: Barrier Island Microfacies}

\subsubsection{B1: Foraminifera Packstones/Grainstones}

This microfacies consists of benthic foraminifera such as Orbitolina within a carbonate 


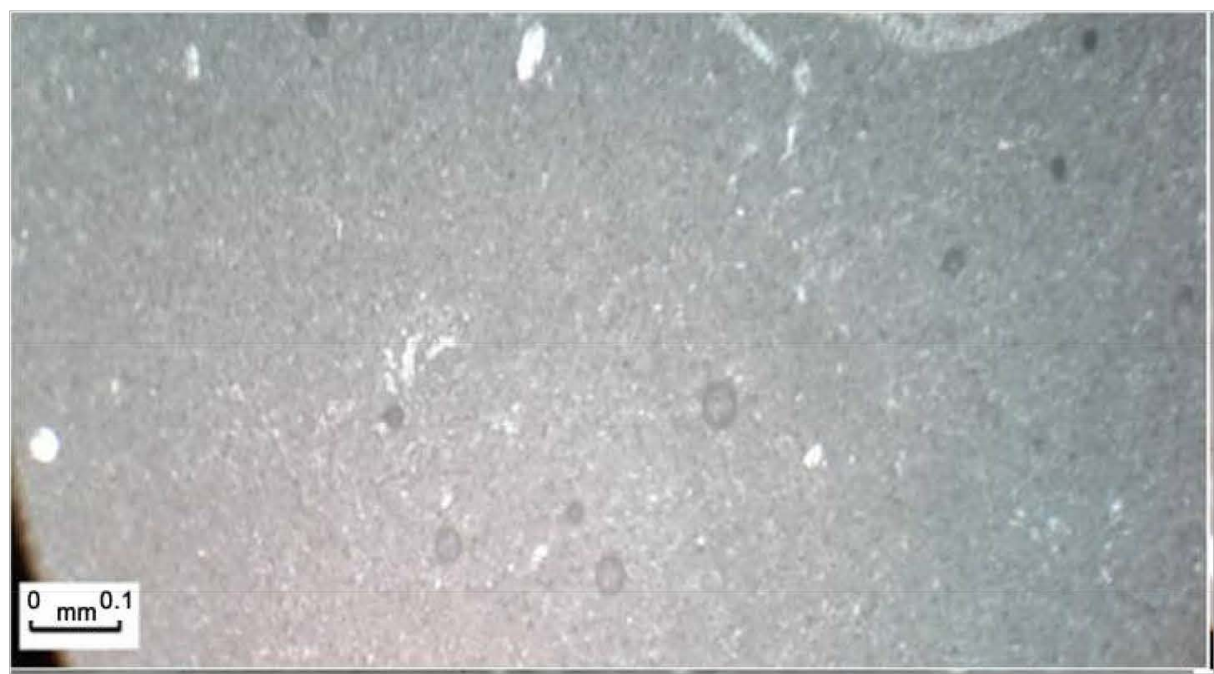

A1: Crinoid, Planktonic bioclastic Mudstone

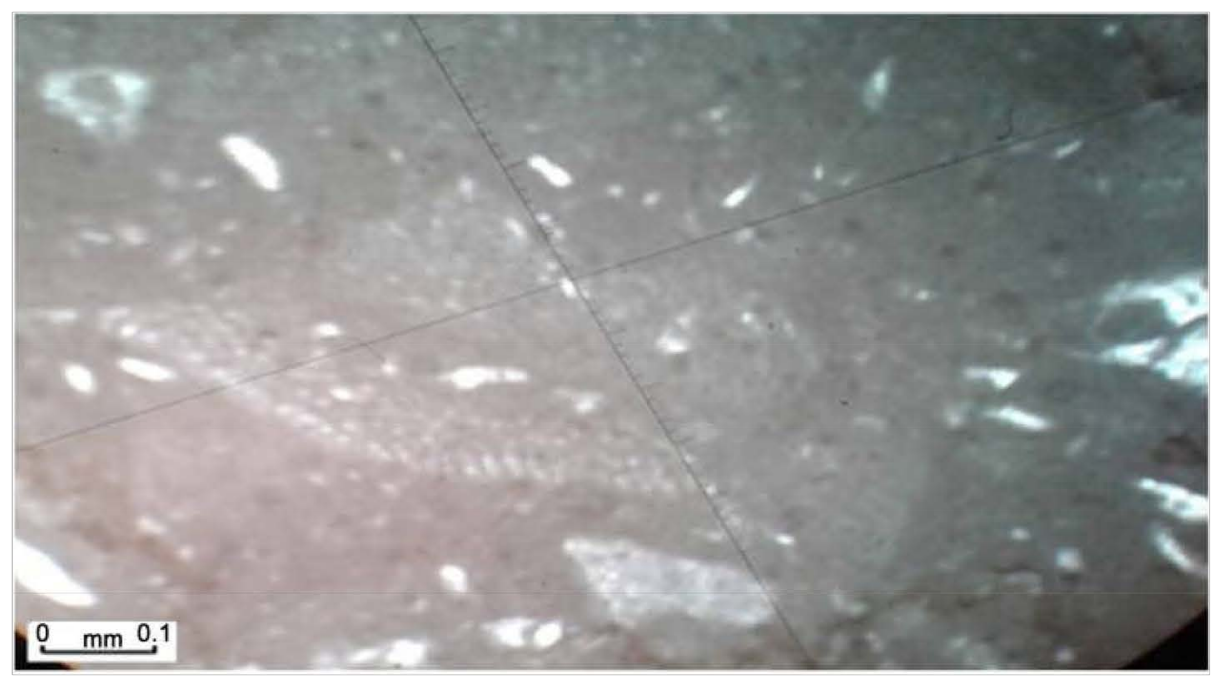

A2: Skeletal Wackstone

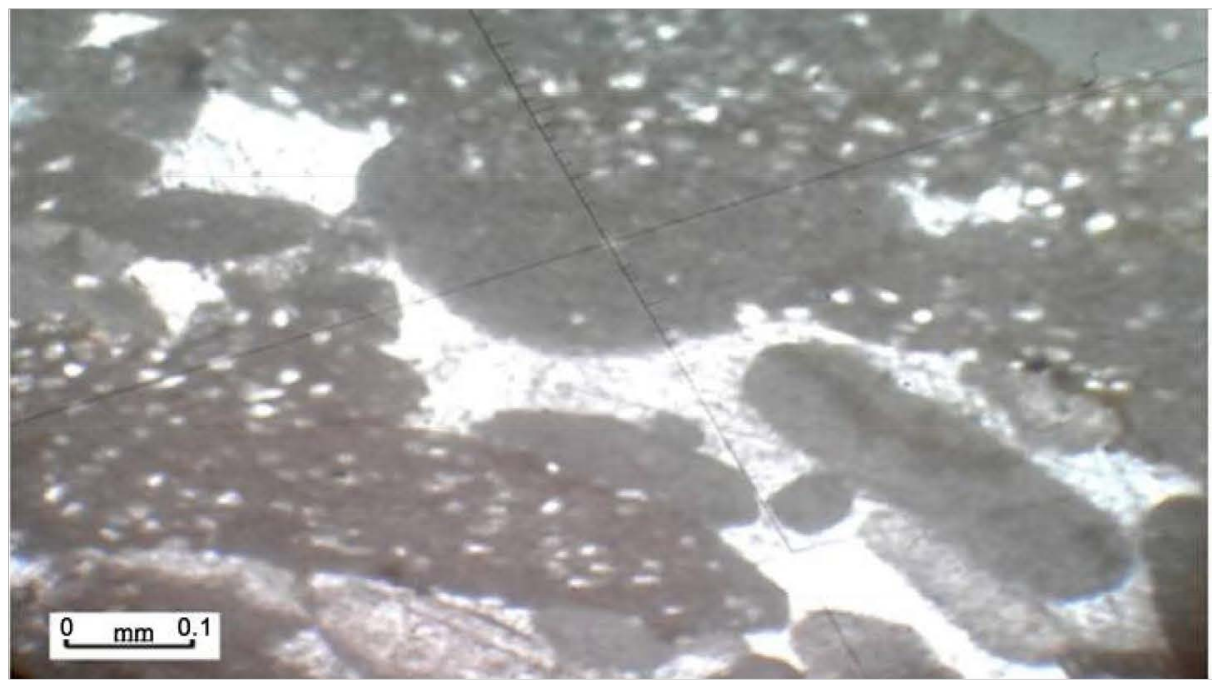

B1:Foraminifera Packstone/Grainstone 


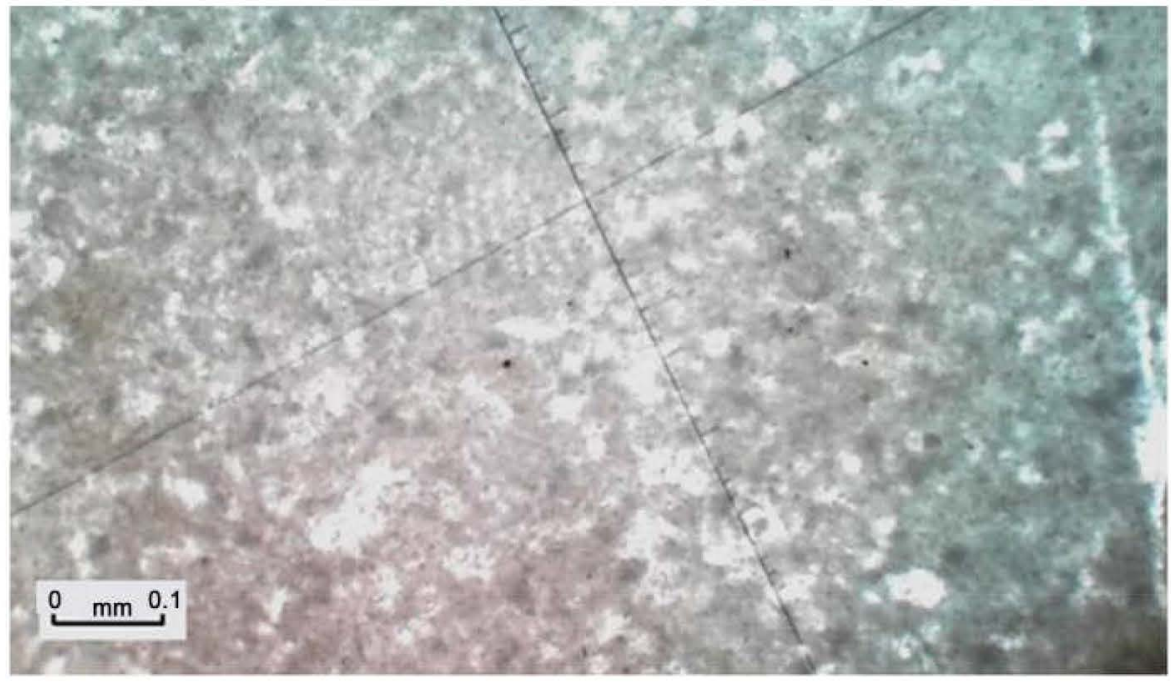

B2: Bioclastic Packstone/Grainstone

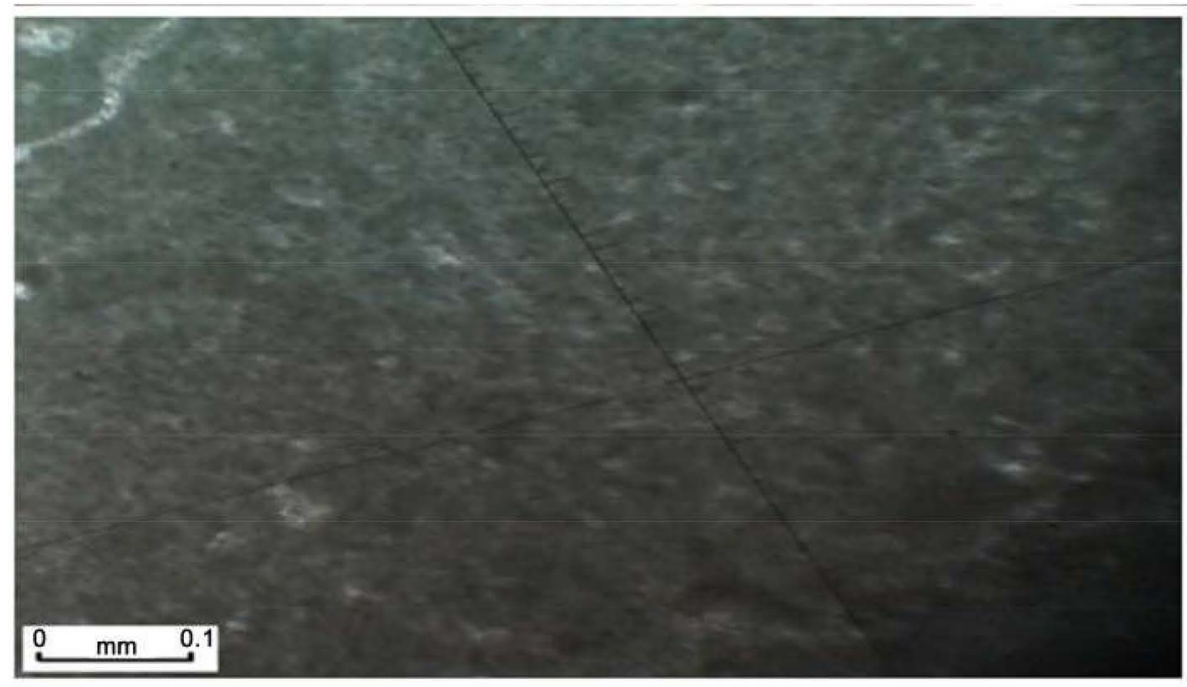

C1: Peloidal Wackstone/Packstone

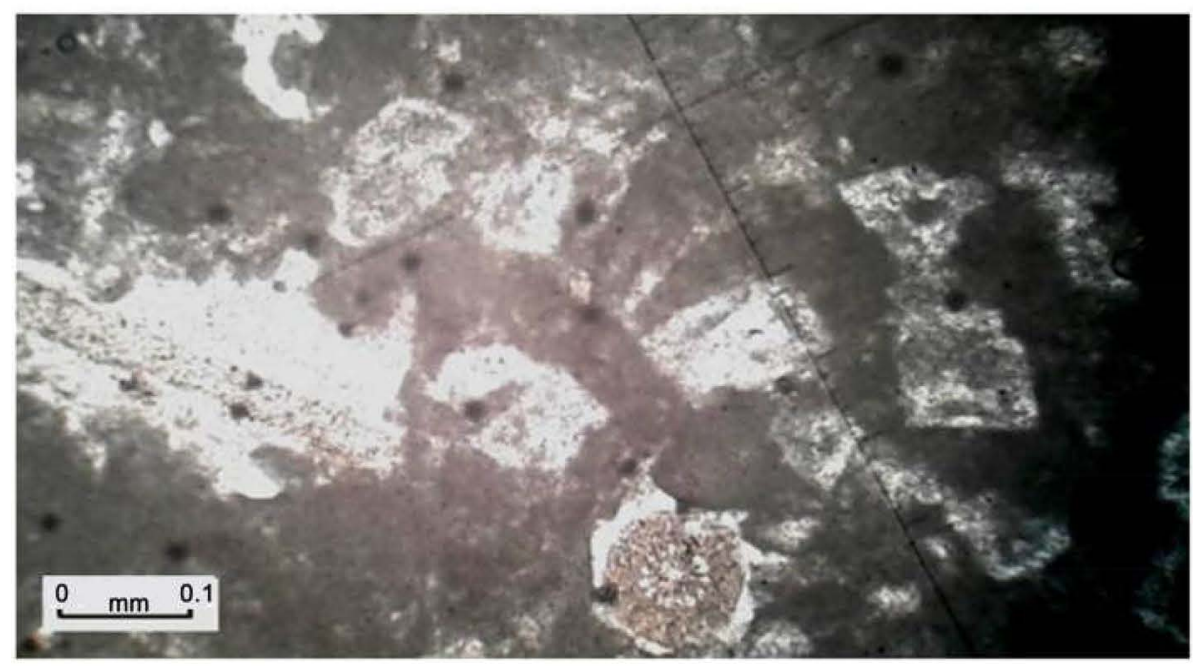

C2: Peloidal Bioclastic Packstone/Wackstone 


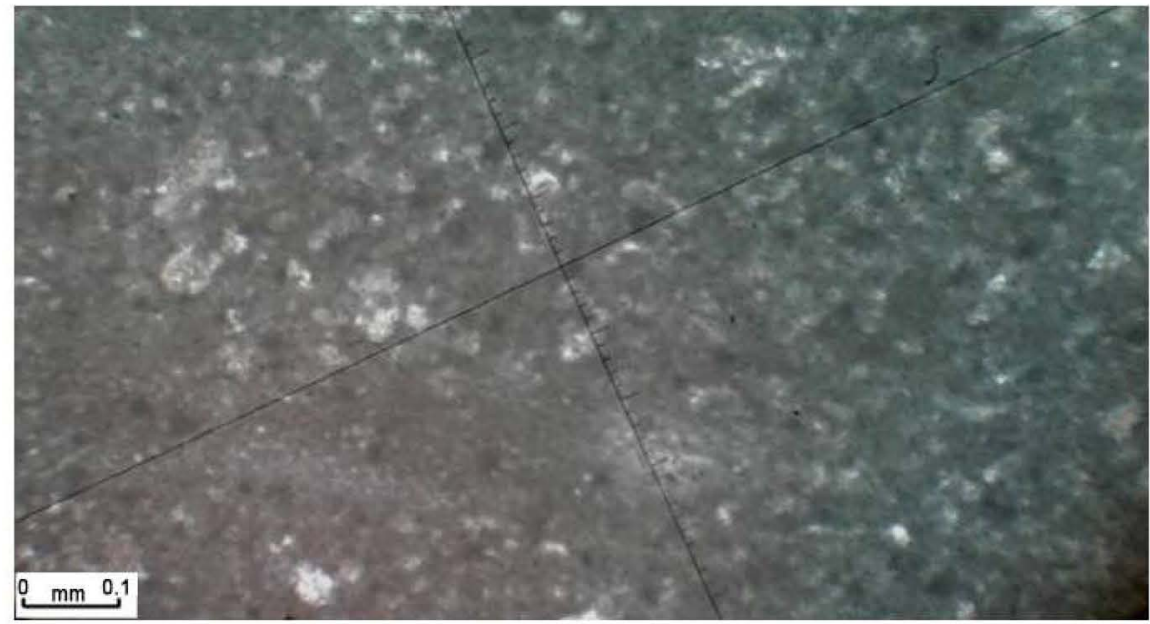

C3: Bentic Foraminifera Peloidal Packstone/Wackstone

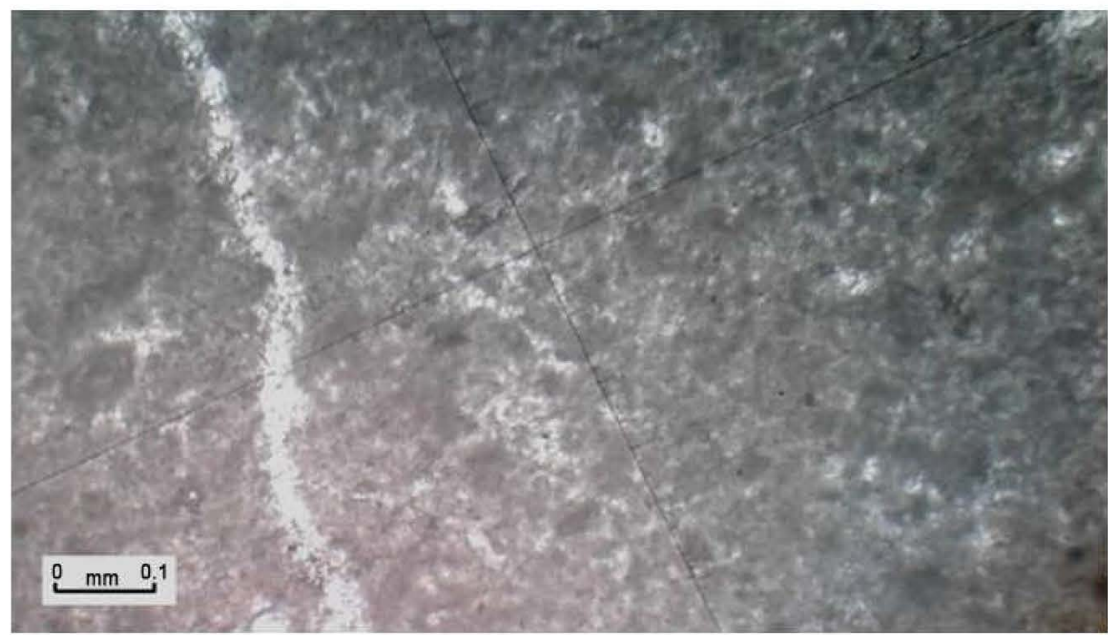

C4: Peloidal Milliolidae Packstone /Wackstone

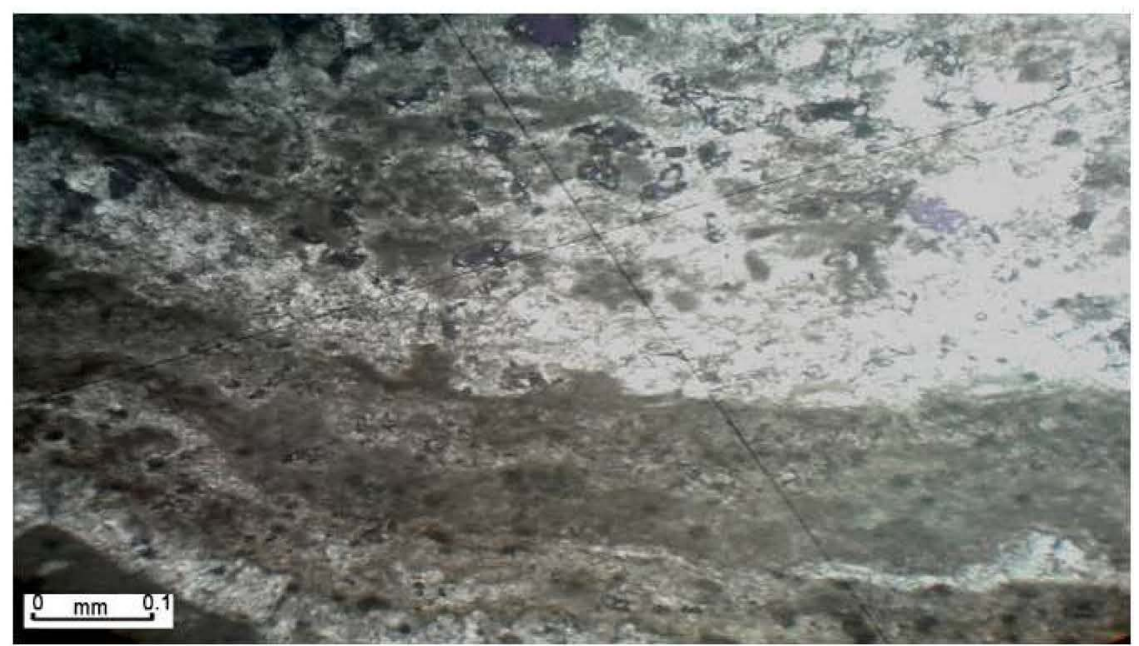

C5: Algal Boundstone

Figure 2. Microfacies of dariyan formation in studied section. A-open marine, B-barrier island and C-lagoon facies belt. 
micritic matrix with sparitic cement. The presence of conical Orbitolina [7] and the textural characteristics, indicate the proximity to a barrier island environment.

\subsubsection{B2: Bioclastic Packstones/Grainstones}

In this microfacies major components are bivalve debris (15\%), benthic foraminifera (10\%) and intraclasts (10\%). Sparite cement and intraclast debris point to a high-energy barrier island environment.

\subsection{C: Lagoonal Microfacies}

Skeletal debris in lagoonal conditions consists of different types of foraminifera including agglutinated (Orbitolina) and porcellanose (Milliolide) forms, as well as green algae and with pelloids. All these features point to shallow and protected normal salinity environments [6].

\subsubsection{C1: Peloidal Wackstones/Packstones}

Peloids and peloidal skeletal debris are major components of this microfacies, bound by lime micritic matrix with some cement, probably indicating temporary exposure and bird-eyes infills.

\subsubsection{C2: Pelloidal Bioclastic Packstones/Wackstones}

Most commonly organic debris in this microfacies is green algae $(5 \%-10 \%)$, peloids $(20 \%-30 \%)$ and brachiopod and bivalve debris (5\% - 10\%). Presence of green algae and peloids in micritic matrix show restricted conditions in lagoonal environments (e.g., [6]).

\subsubsection{C3: Benthic Foraminifera Peloidal Packstones/Wackstones}

Major allochems in this facies are semi-rounded peloids (25\%) and benthic foraminifera such as Orbitolina, Milliolidae and Textularia (10\% - 20\%) with micritic cover. This microfacies is related to lagoonal environments with normal salinity (e.g. [5] [8]).

\subsubsection{C4: Peloidal Milliolide Wackstones/Packstone}

Major allochems in this facies are semi-rounded peloids (25\%) and benthic foraminifera such as Orbitolina, Milliolidae and Textularia (10\% - 20\%) with micritic cover. This microfacies is related to lagoonal environments with normal salinity (e.g. [5] [8]).

\subsubsection{C5: Boundstones}

Carbonates in this facies consist of Lithocodium algae (40\%-50\%), which capture and bound other carbonate particles and matrix, originating boundstone textures [9]. Lithocodium may be related to normal salinity and oxygenated condition environments, such as temporarily open coastal lagoons [10].

\section{Depositional Model}

Major Based in facies properties and their vertical and horizontal variations, according to with notice to Walther's Law and previous sedimentary models (e.g. [5] [11]), Darian Formation's carbonates are interpreted as representing a carbonate platform. Accord- 
ing to gradational facies variations and lack of sudden facies variation, such as slump or breccia deposits, a carbonate homoclinal ramp was considered for this studied section (e.g. [12]). Faciesvariation in this kind of ramps are controlled by: balance between sedimentary supply and accommodation, sea level changes, basin physiography, beach line, environmental energy and terrigenous sediments input [13]. Three facies belt were determined for the studied section, consisting of: A) Open Marine; B) Barrier Island; C) Lagoon (Figure 3_and Figure 4).

According to ramp classification of Reed (1982) [14], Darian Formation was deposited in homocline ramp similar to the present-day Shark Bay in Western Australia or Coast Emirates in the Persian Gulf. Barrier Island and Lagoonal microfacies were part of an inner ramp, while the Open Marine microfacies made part of the outer ramp. This interpretation is comparable with other recent studies [15].

\section{Sequence Stratigraphy}

In order to determine the sequence pattern of the Darian Formation, variations and migrations of sedimentary facies were addressed. This formation consists of two

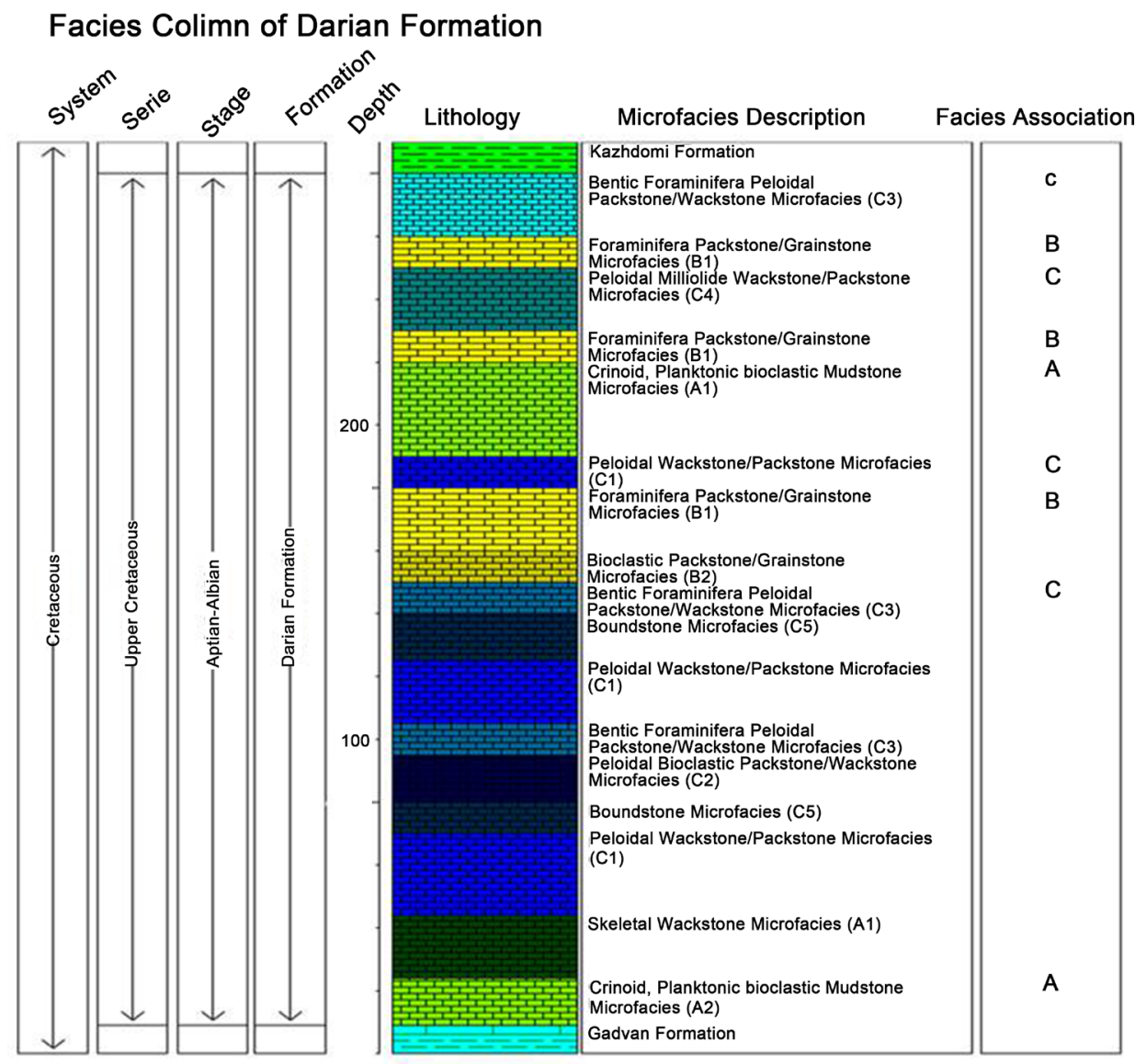

Figure 3. Facies column of dariyan formation in studied section, indicating its microfacies description and association into interpreted facies belts (A-open marine; B-barrier island and C-lagoonal; see also Figure 4). 


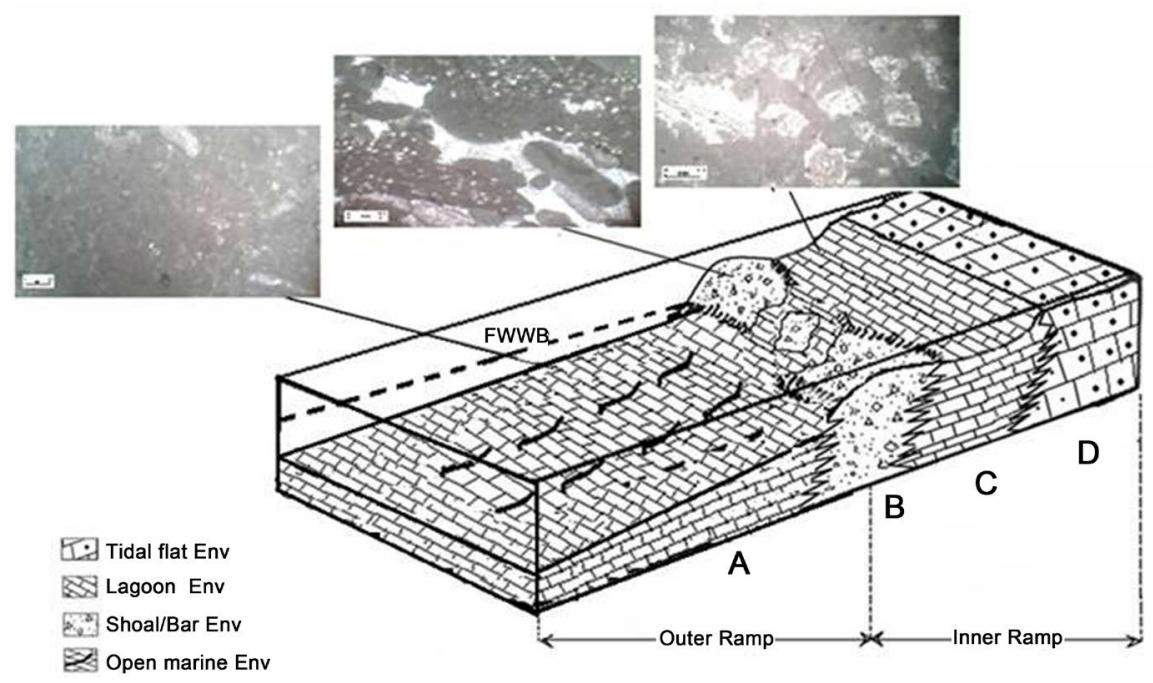

Figure 4. Example depositional environment model for dariyan formation. Note-no tidal flat deposits were identified in the studied section, although they are expected to exist in other areas (e.g. [1]).

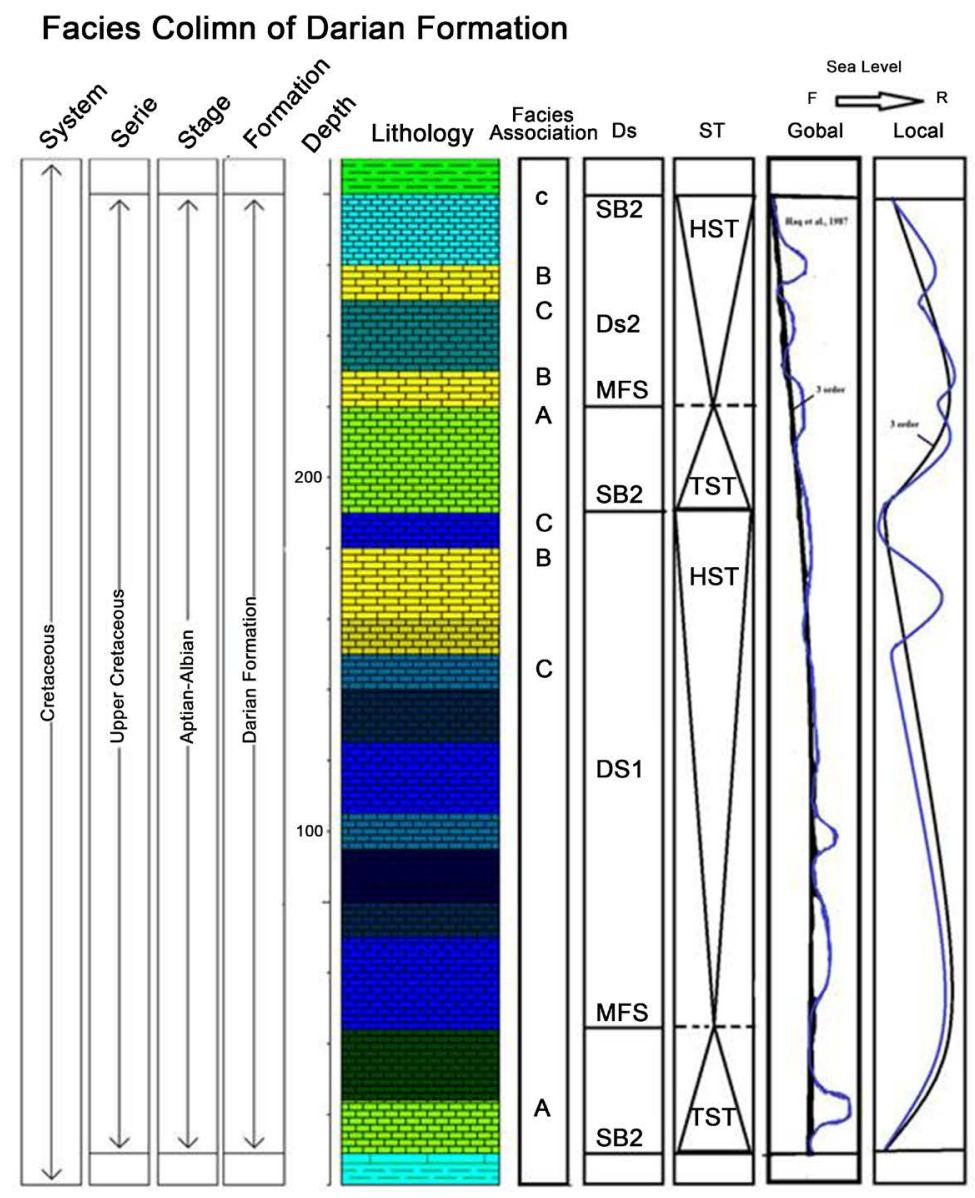

Figure 5. Sequence stratigraphic column of dariyan formation in the studied section, with indications about facies associations (A to C), Dariyan sequences (DS), system tracts (ST), and global and local eustatic curves. 
3rd order sequences separated by a non-erosional contact (Figure 5). Each of these sequences consists of a TST and a HST system tract. Transgressive system tract consists of deepening para-sequences with Lagoonal, Barrier Island and Open Marine situations. Highstand system tract consists of shallowing para-sequences with lagoonal and barrier island situations. According to correlation between global sea level changes [16] and sequence stratigraphy in the studied section (Figure 5), the control seems to have been mainly by global sea level changes, but local tectonic effects such as faulting should not be ignored.

\section{Paleogeography}

Taking into account facies variations and coast level displacements within time, four paleogeographic stages may be considered for the in Lower Cretaceous Darian Formation (Figure 6):

1) Transgressive conditions and TST promoted accommodation space for the accumulation of thick deposits in Open Marine conditions.

2) Shallowing para-sequences (HST) gave place to Lagoonal and Barrier Island facies.

3) A second HST and further progradation promoted again the accumulation of Open Marine facies. Upper contact of this facies shows a MFS.

4) Shallowing para-sequences (HST) gave place again to Barrier Island and Lagoonalfacies.
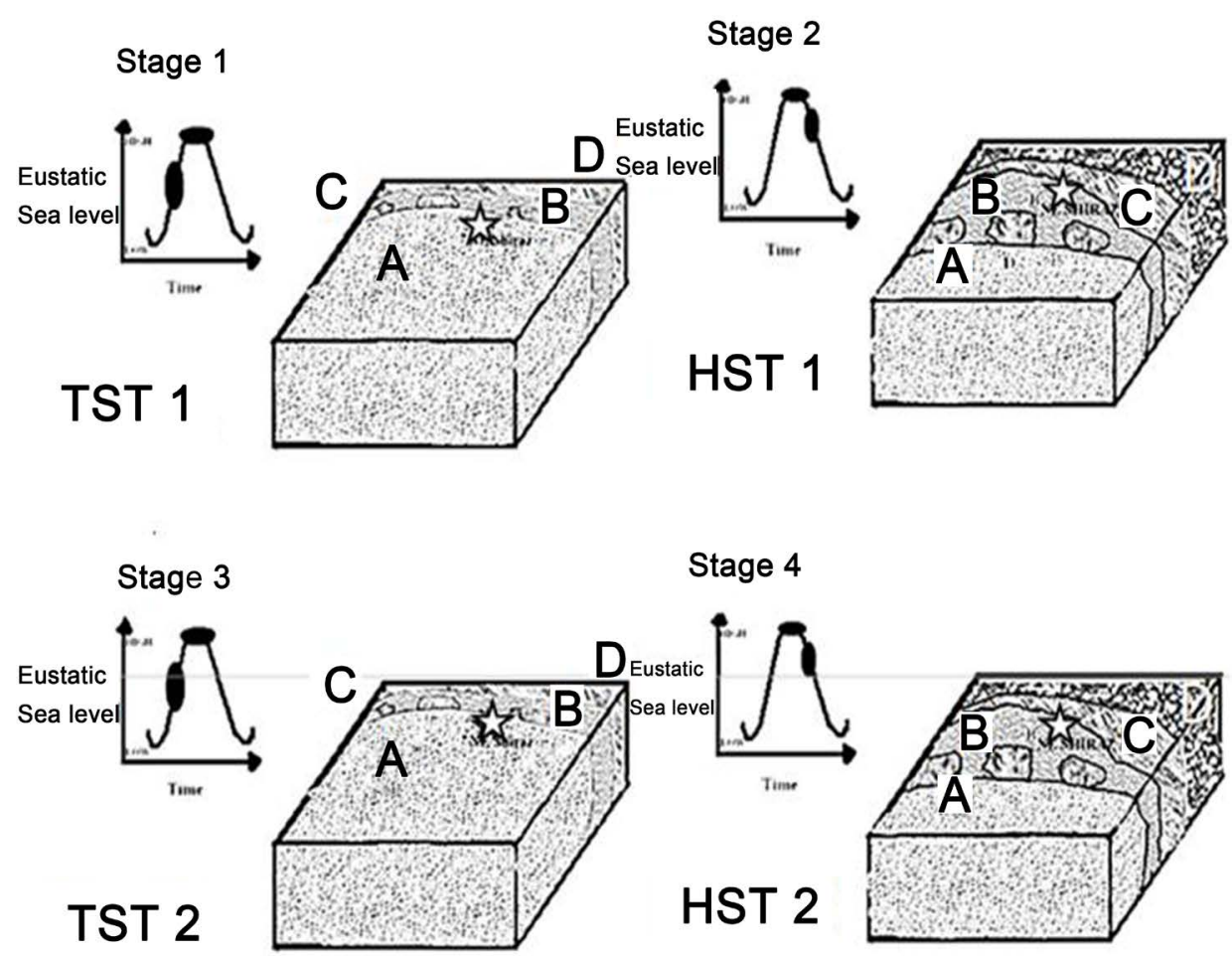

Figure 6. Paleogeographic stages in lower cretaceous Dariyan formation. A. B, C and D indicate the paleoenvironments represented in Figure 4. The small star indicates the location of the studied section. 


\section{Conclusion}

Petrographic studies of Lower Cretaceous Darian Formation have identified 9 carbonate microfacies related to 3 facies belt-Open Marine, Barrier Island and Lagoonal. These paleoenvironments were articulated as part of a homocline ramp. Two 3rd Order sequences with non-erosional contacts were defined, each one consisting of Open marine TST deposits, followed by Barrier Island and Lagoonal deposits (HST). Four paleogeographic stages may therefore be defined for the Dariyan Formation in the studied section.

\section{References}

[1] Moteie, H. (2003) Geology of Iran, Zagros Stratigraphy (in Persian). Geological Survey of Iran, $583 \mathrm{p}$.

[2] Mehrabia, H., Rhimpour-Bonaba, H., Hajikazemib, E. and Esrafili-Dizajia, B. (2015) Geological Reservoir Characterization of the Lower Cretaceous Dariyan Formation (Shuaiba Equivalent) in the Persian Gulf, Southern Iran. Marine and Petroleum Geology, 68, 132157.

[3] Naderi-Khujin, M., Seyrafian, A., Vaziri-Moghaddam, H. and Tavakoli, V. (2016) Characterization of the Late Aptian Top-Dariyan Disconformity Surface Offshore Iran: A MultiProxy Approach. Journal of Petroleum Geology, 39, 269-286.

[4] Dunham, R.J. (1962) Classification of Carbonate Rocks according to Depositional Texture. American Association of Petroleum Geologists, 1, 108-121.

[5] Flügel, E. (2004) Microfacies Analysis of Limestone. Springer Verlag, Berlin, 976 p.

[6] Bachmann, M. and Hirsch, F. (2006) Lower Cretaceous Carbonate Platform of the Eastern Levant (Galilee and the Golan Heights): Stratigraphy and Second-Order Sea-Level Change. Cretaceous Research, 27, 487-512. https:/doi.org/10.1016/j.cretres.2005.09.003

[7] Carozzi, A.V. (1989) Carbonate Rock Depositional Models. A Microfacies Approach, Prentice Hall, 640 p.

[8] El-Asmar, H.M., Assal, E.M., El-Sorogy, S.E. and Youssef, M. (2015) Facies Analysis and Depositional Environments of the Upper Jurassic Jubaila Formation, Central Saudi Arabia. Journal of African Earth Sciences, 110, 34-51. https:/doi.org/10.1016/j.jafrearsci.2015.06.001

[9] Koch, R., Moussavian, E., Ogorelec, B., Skaberne, D.I. and Bucur, I. (2002) Development of a Lithocodium (syn. Bacinella irregularis)-Reef-Mound-Apatch Reef within Middle Aptianlagonal Limestone Sequence near Nova Gorica (Sabotin Mountain, W-Slovenia). Journal of Geologija, 45, 71-90. https:/doi.org/10.5474/geologija.2002.006

[10] Pittet, B., Van Bachman, F., Hillgartner, H., Razzin, P., Grotsch, J. and Drostes, H. (2002) Ecological Succession, Paleoenvironmantal Change, and Depositional Sequences of Barremian-Aptian Shallow-Water Carbonates in Northern Oman. Sedimentology, 49, 555-581. https:/doi.org/10.1046/j.1365-3091.2002.00460.x

[11] Thomas, S., Loser, H. and Salos, R. (2008) Low-Light and Nutrient-Rich Coral Assemblages in an Upper Aptian Carbonate Platform of the Southern Maestrat Basin (Iberian Chain, eastern Spain). 1-26.

[12] Burchette, T.P. and Wright, V.P. (1992) Carbonate Ramp Depositional Systems. Sedimentary Geology, 79, 3-57.

[13] Olivier, N., Pittet, B., Werner, W., Hantzpergue, P. and Gaillard, C. (2008) Facies Distribution and Coral-Microbialite Reef Development on a Low-Energy Carbonate Ramp (Chay 
Peninsula, Kimmeridgian, Western France). Sedimentary Geology, 205, 14-33.

https:/doi.org/10.1016/j.sedgeo.2007.12.011

[14] Read, J.F. (1982) Carbonate Margins of Passive (Extensional) Continental Margins Types, Characteristics and Evolution. Tentonophysics, 81, 195-212.

https:/doi.org/10.1016/0040-1951(82)90129-9

[15] Shirazi, M.P.N. and Rezaei, M. (2015) Microfacies and Sedimentary Environment of the Dariyan Formation from Banesh (North and Northwest of Shiraz, Iran). Journal of Biodiversity and Environmental Sciences, 6, 496-502.

[16] Haq, B.U., Hardenbol, J. and Vail, P.R. (1987) Chronology of Fluctuating Sea Levels since the Triassic. Science, 235, 1156-1167. https:/doi.org/10.1126/science.235.4793.1156

\section{Submit or recommend next manuscript to SCIRP and we will provide best service} for you:

Accepting pre-submission inquiries through Email, Facebook, LinkedIn, Twitter, etc. A wide selection of journals (inclusive of 9 subjects, more than 200 journals)

Providing 24-hour high-quality service

User-friendly online submission system

Fair and swift peer-review system

Efficient typesetting and proofreading procedure

Display of the result of downloads and visits, as well as the number of cited articles

Maximum dissemination of your research work

Submit your manuscript at: http://papersubmission.scirp.org/

Or contact ojg@scirp.org 